\title{
More competent thus more legitimate? MPs' discourses on deliberative mini-publics
}

Citation : Rangoni, S., Bedock, C. \& Talukder, D. More competent thus more legitimate? MPs' discourses on deliberative mini-publics. Acta Politica (2021). https://doi.org/10.1057/s41269021-00209-4

Sacha Rangoni, Université libre de Bruxelles ${ }^{1}$

Camille Bedock, Sciences po Bordeaux, CNRS

David Talukder, Université libre de Bruxelles

\begin{abstract}
:
MPs face a dilemma when it comes to deliberative mini-publics (DMPs): in a context of distrust they may see it as an opportunity to re-legitimize themselves and solve complex policy issues. But it could also challenge the quasi-monopoly they used to have on political decisions and undermine the role of the Parliament and the primacy of elections. The article is founded on 91 face-to-face interviews with French-speaking Belgian MPs sitting in federal or regional parliaments. First, we describe the profile of supporters of DMPs. We then identify three idealtypical discourses: the power-sharing discourse, the consultative discourse, and the elitist discourse. The contribution of this article is twofold. First, it analyzes the argumentative frames used by MPs to assess deliberative mini-publics using a large number of interviews. Second, it demonstrates that their discourses depend on their evaluation of ordinary citizens' competence to participate and on their resulting vision of representation. Political actors mainly perceive DMPs as power-sharing instruments that would alter their elected position and the legitimacy of the election.
\end{abstract}

Keywords: Mini-publics, MPs, representative democracy, political competence, deliberative democracy

\footnotetext{
${ }^{1}$ The order of the authors was draw by lot. Their implication in the research and writing process was equivalent.
} 


\section{Introduction}

Reforms of representative democracy and participatory reforms and experiments are often portrayed as an answer to the democratic crisis (e.g. Reuchamps and Suiter 2016; Newton and Geissel 2012; Smith 2009). Since the 1990s, democratic theory has experienced a strong "deliberative turn" (Goodin 2008). This has led to the development of mini-publics to implement deliberation in practice (Fournier et al. 2011; Grönlund et al. 2014; Reuchamps and Suiter 2016). Deliberative mini-publics (DMPs) can be defined as "specially commissioned deliberative forums, typically sponsored by a government (...) to deliberate about subject matter chosen by their commissioning body" (Pateman 2012, p. 8). Participants are chosen randomly, facilitators and experts guide deliberation, and a report and recommendations are provided at the end of the process. Deliberative democracy is supposed to carry many virtues: it can "deepen democracy" (Fung and Abers 2003); and can "complement (...) representative democracy" (Chambers 2003, p. 308) to bring about constitutional change (Reuchamps and Suiter 2016), to empower citizens (Warren and Pearse 2008); or to overcome deep social or political antagonisms (Parkinson and Mansbridge 2012). Between 2000 and 2020, at least 127 deliberative mini-publics took place all over Europe (Paulis et al. 2020).

Recent studies show how different political parties use deliberation to present alternatives to traditional aggregative forms of intra-party democracy (Gherghina et al. 2020). Other works demonstrate that citizens' opinions on DMPs vary according to their prerogatives (Bedock and Pilet 2020; Rojon et al. 2019), their evaluation of their own competence and that of their fellow citizens, their level of trust, and that supporters of DMPs and of other forms of citizen participation do not fully overlap (Bedock and Pilet 2020; Christensen and von Schoultz 2019; Gherghina and Geissel 2020). Several works compared the perceptions of MPs and citizens of legislatures selected by lot (Jacquet et al. 2020; Vandamme et al. 2018). Finally, 
exploratory studies in Belgium have looked at the discourses of MPs and stakeholders on deliberation (Jacquet et al. 2015; Niessen 2019) or democratic innovations more generally (Schiffino et al. 2019), but rely on a limited number of interviews.

We chose to study MPs because they are the embodiment of representative democracy and are one of the veto players when it comes to changing the rules of the game (Bedock 2017). We investigate the following research question: how do MPs conceptualize, evaluate, and apprehend deliberative mini-publics? MPs face a fundamental dilemma when it comes to deliberative mini-publics. On the one hand, DMPs may endanger the quasi-monopoly they currently have on political decisions. DMPs can undermine the legitimacy which MPs acquire through elections, thereby redefining the role of the Parliament, which is supposed to be the privileged place where deliberation takes place. On the other hand, the implementation of deliberative mini-publics could help MPs regain their legitimacy in a context of political distrust but can also benefit from citizens' input to solve complex policy issues.

Thanks to the inductive coding of 91 interviews, we study the case of French-speaking Belgium. In the theoretical section, we show that DMPs and elections do not rely on the same premises and types of legitimacy. The second section justifies the choice to focus on Frenchspeaking Belgium and describes the data and methodology. The third section describes the profile of the supporters of binding and consultative DMPs. The fourth section shows that MPs develop three ideal-typical discourses on DMPs. These discourses fundamentally depend on their evaluation of ordinary citizens' competence to participate and on the resulting vision of representation. MPs primarily see DMPs as a power-sharing instrument potentially challenging the primacy of the election rather than as a process centered on the quality of deliberation. The last section discusses our results and present our typology of MPs' discourses. 


\section{A clash of legitimacy: (re)legitimization through deliberation or protection of the legitimacy of the election?}

\subsection{Party and individual characteristics and attitudes towards democratic innovations}

The existing literature on party and individual characteristics and attitudes towards democratic innovations (DIs) tends to show that support for DIs is related with vested interests in the existing political system. Parties and individuals that have greater access to political power and a more consolidated position within the political system are less likely to support innovations enhancing citizen participation.

At the party-level, left-wing political forces are more supportive of various democratic reforms compared to center and right-wing parties. Left wing political parties are more likely to support the introduction of gender quotas (Lovenduski and Norris 1993), instruments of participatory democracy (Gourgues 2013) or participatory budgeting (Sintomer et al. 2016). Regarding direct democracy, historical works focusing on the $19^{\text {th }}$ century Populist Party in the US (Lawrence et al. 2009) or on the Green Party in Germany in the 1990s (Scarrow 1999) suggest that left-wing parties pushed for the introduction of direct democratic mechanisms. Other studies found that over the last decades, radical right representatives are particularly favorable to direct democratic reforms (Best 2020; Mudde 2007). Finally, works focusing on support for mixed chambers including politicians and MPs show that, in Belgium, left-wing parties are the most supportive - or the least opposed - to sortition (Jacquet et al. 2020; Vandamme et al. 2018). Left-wing ideology can be associated with egalitarian values and a search for a more inclusive economic and political process. Particularly, parties such as the Greens support democratic innovations that embody post-materialist aspirations and promote a horizontal and grassroots form of political organization (Junius et al. 2020). Referendums 
constitute unmediated and plebiscitary instruments for radical right parties to take back control from the elite (Junius et al. 2020).

The level of access of a given political party to central positions of powers also affects perceptions of democratic innovations. A case study in Belgium shows that candidates who belong to outsider political parties are more critical of representative democracy (Niessen et al. 2019). Comparative work on MPs conducted across Europe suggests that traditional governing parties are less favorable of initiatives that would enhance citizen participation (referendums, deliberation, or participation outside of elections) than anti-establishment parties, radical left parties, and parties with a limited access to power (Núñez et al. 2016). Members of the governing coalition are also less likely than opposition parties to support changes to the status quo, such as compulsory voting, term limits, or the use of citizens' initiatives (Bowler et al. 2002, 2006).

Individual characteristics and political resources also matter. There is a crucial difference between top-level politicians holding prestigious positions and those who are at the margins of power structures. Niessen et al. (2019) show that Belgian candidates who have previously held an elected office are less critical of representative democracy. Comparative research of municipal councilors in Europe that focus on the desirability of citizen participation outside of elections shows that women are more supportive of participatory reforms than are men (Heinelt 2013). However, this result does not hold for female mayors, and there are vast regional differences (Vetter et al. 2018). These results suggest the effect of the level of marginality in the political field is more prominent rather than gender per se. For instance, a study focusing on the case of Ségolène Royal in France, shows that she defended participatory democracy to overcome her marginality within the Socialist Party (Sintomer and Talpin 2011). More generally, certain French politicians have used citizen participation as a way to build an alternative form of political capital (Petit 2017). However, several authors who rely on 
qualitative studies in France, suggest that gendered political socialization may also influence opinions on participatory democracy: participation mobilizes so-called "feminine" qualities such as conflict avoidance or listening (Paoletti and Rui 2015). This may explain why women have been more supportive of mixed chambers, including putting citizens alongside elected politicians in Belgium (Vandamme et al. 2018).

In conclusion, party ideology and access to political power condition the support for various democratic innovations that would enhance citizen participation. We still have to establish whether these findings also hold for the particular case of DMPs (Section 4). The mechanism explaining why certain politicians are more likely to be in favor of DMPs specifically should also be clarified. We argue that MPs' position is related with the incompatibility of the legitimacy of elections and mini-publics.

\subsection{A clash of legitimacy? Elections vs. deliberative mini-publics}

Political elites are evolving in a political environment where participatory and deliberative experiments are increasingly valued and institutionalized. From the point of view of politicians, DMPs can be viewed in two ways: as redistributive institutions, which improve the condition of one group, citizens, at the expense of another group, politicians; or as efficient institutions (which improve the condition of all groups, see Tsebelis 1990). If DMPs are perceived as redistributive institutions, then actors would focus on the fact that deliberative experiments lead to a redistribution of power between MPs and ordinary citizens, and question the legitimacy of elected representatives. Conversely, if political actors perceive DMPs as efficient institutions, then they would focus on the "win-win" situations that a highly legitimate and deliberative process could create, and on their ability to solve complex policy issues. 
DMPs challenge the legitimacy of elections more directly than other form of democratic innovation, because they involve the use of sortition. The legitimacy of elected representatives lies on accountability (Urbinati and Warren 2008) and on delegation (by taking decisions in the best interest of the represented). Moreover, the voting mechanism ensures that the most competent candidates (in terms of education, internal efficacy, oral proficiency) are chosen (Vandamme 2018), since representative democracy is based on the concept of a hierarchy of competence between the represented and the representatives (Manin 1997). The time spent in politics by professional politicians, the acquisition of specific skills, or a specific professional background, has led to the professionalization of politics (Boelaert et al. 2017).

Qualitative studies conducted in Belgium that examined how political elites conceive democracy suggest that this elitist conception of representation allows us to understand MPs' positions on deliberative democracy. While certain MPs are ready to accept a hybridized form of democracy, in which elections are complemented by other forms of participation, the centrality of elected representatives in the decision making-process remains unavoidable. This discourse is linked with the belief that representatives are legitimate because they are particularly competent and able to defend the general interest, unlike the average citizen (Jacquet et al. 2015; Schiffino et al. 2019). Belgian MPs appear widely opposed to sortition of political offices when their decision-making power is more than consultative, even if leftist MPs tend to be in favour of mixed assemblies (involving elected and sortitioned members). Among citizens, random selection seems to especially appeal to disaffected citizens with a lower social status (Jacquet et al. 2020; Vandamme et al. 2018).

Conversely, sortition, the guiding principle of DMPs, is fundamentally different from election. Sortition relies on descriptive representativeness and on the likeliness between the representatives and the represented. It avoids the risk of a self-selection bias, provides equal 
opportunity for each citizen to participate and generates diversity among decision makers (Vandamme 2018). It is also supposed to foster deliberation, openness to other people's arguments (as members of deliberative mini-publics do not defend a political program and are not bounded by party discipline) and the ability to take long-term consequences of political actions into consideration (Vandamme 2018). Unlike instruments such as direct democracy or elections, which allow everyone to take part in the process, DMPs are based on the participation of a small number of citizens, with an equal chance of being selected. This also challenges the nature of representative democracy in which the legitimacy of the representatives emanates from the consent of the people who remain sovereign. DMPs leave the influence of the maxipublic out of the equation (Farrell et al. 2020).

The legitimacy and the advantages of election and sortition may be complementary, specifically if the prerogatives of citizens selected through sortition remain consultative (Vandamme 2018). Moreover, in a context of distrust of elected politicians, of increasing complexity of policy issues, and of demands for citizen participation, MPs could accept DMPs and acknowledge the advantages of sortition and deliberation. On the other hand, elected politicians could perceive DMPs as a zero-sum game, which implies that delegating a portion (even consultative) of their prerogative might diminish their power, and undermine the legitimacy of elections.

\section{Case selection, material and methodology}

\subsection{French-speaking Belgium as a laboratory for DMPs}

French-speaking Belgium is a particularly interesting case to study the perceptions of deliberative mini-publics among elected representatives, as it combines strong political parties and multiple recent experiments of deliberative mechanisms at the federal and local level (Vrydagh et al. 2020). Belgium is a divided and pillarized society, sometimes labeled as a 
“partitocracy" (van Haute et al. 2013) with two-party systems based on different languages and two distinctive public spheres. Several large-scale deliberative initiatives took place in 201011, during Belgium's longest period without ruling government, thanks to the initiatives of private actors such as the G1000. State actors, such as the Parliament of Wallonia or Brussels and municipalities then took up the subject by organizing several deliberative events in the 2010s (Jacquet et al. 2020). The Parliament of the German-speaking community of Belgium recently created a permanent deliberative citizen assembly linked to the parliamentary process (Niessen and Reuchamps 2020). Both the Parliaments of Brussels and the Parliament of Wallonia voted for the implementation of mixed parliamentary committees with randomly selected citizens and elected MPs. French-speaking Belgium is therefore a laboratory to understand the position of MPs on deliberative mini-publics. Flanders was excluded from the analysis because no DMPs were implemented at the regional level in this region. Frenchspeaking Belgium can be understood as a crucial case (Gerring 2006): MPs have all been subjected to DMPs and the debate is particularly intense on the issue, hence we can expect that their discourses on this issue are more informed by experience that in most other regions or countries.

\subsection{Data and Methods}

We conducted 91 semi-structured interviews with French-speaking MPs sitting in the Federal Parliament, the Parliament of Wallonia, and the Parliament of Brussels between March and July 2018. They represent $43 \%$ of the 210 French-speaking MPs. These interviews took place during the POLPOP project (Elites Perceptions of public opinion, funded by the FPO and coordinated by the University of Antwerp). Our strategy was to obtain a sample as diverse as possible that included all key groups and constituencies (Ritchie et al. 2014). In order to do that, we contacted all French-speaking representatives by e-mail and by phone to set an appointment. 
We have also attended parliamentary sessions in order to conduct interviews with the MPs who were otherwise difficult to meet. When we reached a satisfactory number of respondents, we targeted some MPs with underrepresented profiles in our sample. Nonetheless, our final sample is somewhat asymmetric with an over-representation of MPs from Brussels (see Appendix 1). Our sample mirrors the composition of the three assemblies in terms of gender, even if MPs from certain smaller parties (Ecolo, a Green Party, and DéFI, a French-speaking regionalist party) and members of the majority are overrepresented. In our sample, $41 \%$ of respondents are multiple office holders, which means that thirty-eight MPs are either mayor or alderman, while 59 percent are "only" MPs. Finally, 57\% of our sample has sat in parliament for fewer than three mandates, whereas $43 \%$ have been elected for three mandates or more.

The 91 interviews were mostly held in MPs' offices. During the meeting, the respondent had to first answer a survey unrelated to the topic of this article, after which a short interview was conducted. As DMPs were only addressed at the end, the MPs were more trusting than at the beginning of the interview and gave less "controlled" answers. We asked seven questions about: their definition of participatory democracy their experience with participatory democracy and DMPs at a local, regional and national level, their visions about concrete DMPs organized on population ageing in the Parliament of Wallonia in 2017 or mobility in the Parliament of Brussels in 2017, and their evaluations and ranking about a series of democratic innovations, including consultative and binding DMPs (see Appendix 3). Regarding the last questions, we asked MPs to take an explicit stand and we insisted when they did not give a clear-cut answer. The aim of these interviews was to highlight MPs' discourses on participatory democracy and DMPs more specifically. Each meeting lasted between thirty minutes and one hour, which includes the ten to thirty minute interview. 
Following previous studies on similar topics (Jacquet 2017; Jacquet et al. 2015), and Braun and Clarke's step-by-step guide (2006), we conducted an inductive thematic analysis (Mucchielli and Paillé 2012) to go beyond the simple description and to have a better understanding of the "patterns", or "themes within interviews . Thus, we tried to go "beyond the semantic content of the data, and start to identify or examine the underlying ideas, assumptions, and conceptualisations" (Braun and Clarke 2006, p. 14). After having transcribed, and became better acquainted with the 91 interviews, we coded them thematically. Firstly, we inductively generated initial codes using the data analysis program NVivo 12 (QSR International, UK). Depending on our ability in identifying patterns every groups of words, sentence or group of sentences were counted as coding units. Each coding unit could be coded multiple times, if they referred to several ideas at once. This first step brought out "nodes" found in the text. Secondly, some categories and subcategories have inductively emerged from our data and we managed to obtain a thematic tree of these categories, thereby summarizing MPs' arguments on their definitions, their practices, and their evaluations of DMPs (see Appendix 2). Thirdly, we linked our findings to the existing literature to refine the themes and subthemes. For instance, we realized that the themes we identified inductively corresponded to the participation ladder of Pilet et al. (2007). Fourthly, we rechecked all our codes to obtain a thematic analysis that is as consistent and uniform as possible. By this, we mean that each category or sub-category is internally coherent (“internal homogeneity”) and unambiguously different from other categories or sub-categories ("external heterogeneity")(Patton 2015, p. 811). Lastly, we conducted the final analysis of our corpus by identifying the three ideal-typical discourses, which we develop in section 4 . If the first step of our analysis was fully inductive, we went back and forth between our analysis and the literature during the interpretive phase of our work.

\section{The profile of the supporters of deliberative mini-publics}


Before analyzing the discourses that MPs produce on mini-publics, it is important to establish the profile of the supporters of different types of DMPs (Table 1). MPs who were "totally in favor" or "in favor" a reform were grouped as supporters, and MPs who were "neither for nor against", "against" or "totally against" a reform were grouped as opponents. Less than a quarter of the MPs interviewed (23\%) claim to be in favour of binding mini-publics. Members of the Ecolo party, which is the most active in French-speaking Belgium on this issue (Biard et al. 2020), are by far the most supportive of binding mini-publics (63\% in favour). MPs sitting in the Parliament of Wallonia and Brussels, in which experiments of mini-publics have been taking place in recent years, are much more favourable than MPs sitting in the Federal Parliament. Finally, members of the opposition are also more likely to support binding minipublics: more than a third support this idea, whereas only $14 \%$ of the members of the majority do so. Multiple office holders - MPs who also hold an elected executive office at the local levelare much less supportive of binding mini-publics. Finally, MPs who have been in parliament for fewer than three mandates are much more enthusiastic about binding mini-publics than more experienced MPs: 34\% support them (only 9\% of MPs who have been in the parliament for three mandates or more). This clearly suggests that, as for other democratic innovations, support for DMPs is correlated with ideology and is stronger in opposition parties of the left. MPs with more individual resources - those who sit at the national rather than the regional level, with more parliamentary experience, who sit with the majority and those who hold other local mandates - are more protective of their prerogatives.

There is no typical profile of the supporters of consultative mini-publics as it is supported by $83 \%$ of the MPs. Supporters could be found across the entire ideological spectrum, in the opposition and in the majority, in all three Parliaments, independently of the level of political experience. The only difference is that women are more supportive of consultative mini-publics than men. Finally, a small minority of MPs (13\%) rejected both forms of mini- 
publics. These MPs belong exclusively to certain traditional government parties (MR, PS and DéFI $)^{2}$. None of the women interviewed rejected both mechanisms, whereas this is the case for a fifth of the men interviewed.

[Table 1 around Here ]

These descriptive findings show that support for DMPs is related with ideology, but also with the level of access to political power. More specifically, the link between the level of political experience and support for DMPs strongly suggests that MPs who have more individual resources and a longer political experience develop a stronger commitment to the existing system. The analysis of the discourses of MPs highlights the mechanism behind support for DMPs: the evaluation of citizens' competence and the resulting vision of representation.

\section{MPs' visions and discourses about DMPs}

Through the inductive analysis of the corpus, we identify three ideal-type discourses. MPs' discourses about DMPs are built on two argumentative frames: one related to capacity (considerations about the respective qualities and competences of citizens and elected representatives), the other to the process of representation (how citizens and elected politicians interact). Considerations related to output legitimacy (the evaluation of politicians' and citizens' capacity to produce effective policy outcomes) influence MPs' preferences in terms of process legitimacy (the efficacy, accountability, openness and, inclusiveness of the governance process, Schmidt 2013).

\footnotetext{
${ }^{2}$ Despite not being a classical traditional party, DéFi has been part of almost all the government at the Regional level of Brussels since its creation in 1989, see Talukder in (forthcoming).
} 


\subsection{The power-sharing discourse}

MPs who make a "power-sharing" discourse, support binding forms of deliberative mini-publics organized on major issues. They consider deliberative mechanisms with no ability to constrain the final decision to be useless. For MP 32 (Écolo, Parliament of Brussels),

“The worst disenchantment is not when you're not listened to, it's when you get involved and you don't get listened to".

Because DMPs that have been organized in Belgium have only been consultative, these MPs make a strong case against the dominant implementation of deliberative mini-publics. They consider that participation should not be limited to giving an informed opinion, but should also involve the ability to have a say in the final decision. They further argue that deliberative minipublics and referendums could complement each other, and mention the Swiss model of referendum several times. MPs holding this discourse also consider that mini-publics have to deal with major issues, such as institutional reforms or important societal issues, rather than on mundane issues of the local level. This contrasts with the dominant discourse held by the vast majority of MPs (cf. infra.). These MPs accept a hybrid form of democracy in which participatory mechanisms could exist alongside representative democracy and become a "useful complement of representative democracy” (MP 50, Écolo, Federal Parliament).

The willingness to accept co-decision through binding forms of mini-publics is what distinguishes these MPs from their colleagues. Co-decision implies that elected representatives accept to give at least a part of their "reserved" powers to ordinary citizens. This position is acceptable for those MPs who see themselves as equal to citizens. Indeed, the willingness to hybridize democracy is linked to the way in which these MPs evaluate their own competence and the competence of ordinary citizens. Instead of adopting a position that would place them 
above the citizenry, these MPs stress the universal competence of citizens, including those who are not interested in politics. For MP 11 (PS, Parliament of Brussels), “The politician (...) does not have innate knowledge".

The idea that politicians are not more qualified than other citizens is directly related to the belief that everyone has a legitimate say in the political process. This justifies the use of sortition. MP 66 (MR, Parliament of Wallonia) considers that the most important thing is to listen to all citizens equally, arguing that mini-publics should more specifically be aimed at citizens "who have never done politics and who do not see their views expressed". These MPs value mini-publics as a way to build on collective intelligence. They believe that citizens bring a new perspective on important political issues by challenging the common views found in the Parliament that is structured by partisan politics. For example, MP 26 (Écolo, Parliament of Brussels) argues:

"We realize that people are able to think out of the box (with ideas that are difficult to carry in political parties) and are also able to take constraints into consideration".

This discourse displays classical arguments found in the literature defending deliberative democracy. The latter is seen as fostering collective intelligence and legitimacy by building on the ability of ordinary citizens to tackle complex issues (Reuchamps and Suiter 2016; Warren and Pearse 2008). It relies on the acknowledgement of the positive dynamics inherent to deliberation in mini-publics and on the idea that citizens, experts, and politicians should use it to reach consensual and better-informed decision. The MPs using this argument have often taken part in the organisation of deliberative mini-publics, and have become convinced of their deliberative practical virtues. 
By putting citizens and politicians on equal footing, MPs who hold a power-sharing discourse articulate a vision of political representation that is not limited to Election Day, but based on regular citizen participation and co-decision. These representatives describe representation as a process of "permanent interaction" and of "co-construction" with citizens. For MP 32 (Écolo, Parliament of Brussels),

"We co-construct public policies with an ongoing constructed and constructive dialogue. That means that we don't consider that a political mandate is given only on Election Day, but we consider (...) that elections give responsibilities and that the exercise of those responsibilities involves going back and forth between the representative and his constituency."

Representation is envisioned as a fluid and dynamic process of claim-making by representatives in which consent is not given once and for all: it cannot be reduced to elections and takes place in multiple other settings (Guasti and Geissel 2019; Saward 2010).

\subsection{The consultation discourse}

In this second ideal-type discourse, MPs accept deliberative mini-publics on the condition that they remain optional, consultative, limited to certain topics, and if the final decision is fully controlled by politicians. DMPs are only accepted if the hierarchy between elected politicians and citizens is fully acknowledged. When asked if mini-publics could deal with important issues, such as institutions, cultural, and social issues, these MPs thought that citizen participation should be strictly limited to everyday, ordinary, and local issues: "topics that concern them, such as garbage in the street” (MP 40, PS, Parliament of Brussels). 
These MPs also formulate harsh criticisms on the principle of sortition, which confirms previous findings (Jacquet et al. 2020; Vandamme et al. 2018). Only self-selected citizens who are motivated and competent should take part in participatory (consultative) mechanisms. One of the most telling excerpts is the metaphor used by MP 51 (MR, Federal Parliament):

"If your car breaks down, will you draw by lot someone to know who should repair it? I don't think so".

This purely consultative view of DMPs is linked to the idea that randomly selected citizens are just not qualified enough to make important political decisions on technical issues. For instance, when asked if deliberative mini-publics could tackle institutional issues, MP 19 (PS, Parliament of Brussels) argues:

"No, impossible. When you are an MP it takes you almost a year to understand how the Parliament works, how you come up with proposals, how you help things along, and all of this is so constraining that if we do something like that, I call my grandmother who says, 'Here it is'. No, this makes absolutely no sense”.

This excerpt shows that certain topics are considered as too specialized and technical to be discussed by ordinary citizens. Politics is seen as a profession requiring special skills and technical competences (Jacquet et al. 2015; Schiffino et al. 2019). Denying that this complexity exists amounts to depreciating the competences of MPs. MP 23 (DéFI, Federal Parliament), argues that "there is a political technicality in the functioning of the institutions that the citizens do not know". MP 48 (MR, Federal Parliament) considers that important decisions "are not based on emotions, they are based on reason". Citizens are deemed competent enough to be consulted on topics concerning their everyday life, but not on more complex topics that are the prerogative of competent, dispassionate, and trained politicians. According to these MPs, 
citizens are certainly not competent enough to produce innovative solutions through collective intelligence. The principle of sortition is seen as potentially damaging, because it prevents the selection of the most competent and motivated individuals.

This discourse is often associated with a paternalist view of DMPs, that it is a way to show citizens how hard politics really is. For instance, according to MP 27 (PS, Parliament of Brussels)

"[Citizens] may become more aware of the difficulties of administration, they may choose the party they will vote for differently because they may understand a little better the difficulties that exist, and become more interested in politics".

This MP uses a conditional tone: citizens may, or may not become more aware of the difficulties of public affairs. This argument can be linked with elitist discourses that argue that “sophisticated" citizens are greatly outnumbered by incompetent citizens (Converse 1964).

MPs who hold a consultation discourse also provide definitions of the representative process. Indeed, elections being the only mechanism that ensures accountability remain the cornerstone of democratic legitimacy. Citizens should be regularly consulted outside of elections, but any binding mechanism could endanger the legitimacy of politicians, based on their accountability and competence. Thus, the vision these MPs have of the representation is closely intertwined with considerations about competence. Accordingly, MP 22 (DéFI, Parliament of Brussels) envisions representation as such:

"the possibility for citizens to give their opinion between two electoral periods, to give feedback from the reality of the ground (...) That's the role of a representative, to be accountable not only on Election Day". 
Strikingly, several MPs also share the opinion that sortition does allow for "representative" jury, because it prevents the most motivated citizens to take part in participatory processes. In other words, "representation" is also understood as a form of selfselection of the most competent and the most motivated individuals (Manin 1997). For instance, MP 26 (Ecolo, Parliament of Brussels) argues:

"what I dislike [about drawing lots] is that not all people can participate. There are people who are more motivated, there are people who are less motivated, (...) there are people who cannot write, there are people who cannot speak properly. Therefore, I am in favour of letting all citizens express themselves, and choosing between citizens bothers me, because there is always something that is not representative".

These MPs strongly reject any mechanism that could constrain political decisions. This implies that representative democracy founded on political parties, delegation, and competence, could be challenged or even substituted. MPs consider that binding mini-publics could make them replaceable, and, therefore, redundant. This also explains why MPs who have greater access to political power, are so dismissive of binding mini-publics: DMPs are primarily perceived as instruments that could redistribute political power. For instance, MP 4 (DéFI, Parliament of Brussels) gives the following argument:

"The citizen jury (...) almost replaces politicians, at some level. In that case, I think that is somehow a misuse of participatory democracy, because I wonder what the elected politician is for. (...) I don't claim to be an expert on everything, but I am accountable to the voter at some point to have a small fragment of power which I have to use as well as possible, and that always pisses me off when this small 
fragment that I hold, someone tries to take it away from me to give it to another actor."

This excerpt is particularly telling. This MP clearly draws a hierarchy between representative democracy, election, accountability, and delegation, which are the cornerstone of democratic legitimacy and DMPs. DMPs are only a complement that would strengthen the link with citizens between elections.

\subsection{The elitist discourse}

A handful of MPs used very harsh terms to describe mini-publics: "pseudo-participatory democracy", "window-dressing", "complete bullshit", to name but a few. This very negative judgment is based on the idea that lobbies and partisan groups use DMPs to covertly advance particular interests. MP 44 (PS, federal parliament) rejects citizen juries because

\footnotetext{
“there are a lot of lobbies talking. That's a bit what I call 'Canada-dry' democracy: it looks like democracy, it has the colour of democracy, but it's not necessarily democracy. Because at some point, I truly feel that there are people who are instrumentalized, or who instrumentalize others".
}

The identity of those who manipulate democratic innovations varies according to the political orientation of the MPs. Several MPs belonging to the centre-right and to the liberal party MR (Mouvement réformateur) argue that citizens are the prey of politically organized (leftist) groups. By contrast, some MPs on the left criticized participatory democracy on the ground that it exacerbates far-right populist attitudes that could endanger civil liberties.

These MPs point at the deficiencies of ordinary citizens but they do so more bluntly that they did for the consultation discourse. For instance, MP 57 (PS, Federal Parliament) argues: 
“people are incompetent. (...) There is a great illusion (...), which is to believe that the citizen is able to surpass himself and to think about the general interest".

The representative system is seen as the main guarantee that individuals who are engaged in public life are competent. For MP 54 (MR, Federal Parliament),

"the fact that one is on a list and to stand for an election is already the result of a filter. This already means that, well, you are dealing with people who either are able to represent something, or people who can defend their ideas, people who dare to stand for their ideas".

Citizens are considered as politically incompetent but also as selfish and unable to favour the public interest. This confirms previous results opposing MPs who see themselves as standing for the common good, as opposed to ordinary citizens who are blinded by their individual interests (Jacquet et al., 2015, 186). Theoretical discussions on deliberative minipublics argue precisely the contrary: MPs tend to focus on short-term interests and re-election whereas citizens are more likely to take long-term considerations into account (Vandamme 2018). For MP 56 (MR, Federal Parliament) the citizen "lives in the present, he's into instant gratification". MP 3 (MR, Parliament of Brussels) argues: "The citizen today wants the maximum for a minimal cost". It is striking to note that in the two previous excerpts, citizens are essentialized: these MPs talk of "the" citizen as a single, homogenous and depreciated political figure. In this discourse "the (bad) citizen" is the reversed figure of "the (good) politician". In the general public discourse, many commentators and citizens have a negative evaluation of politicians who are seen as a homogenous, self-serving group that is disconnected from the public interest (Clarke et al. 2018). Yet, these MPs hold a parallel discourse in which "the citizen" is at fault. They adopt a position that Marion Paoletti calls "elective corporatism" (1997) leading them to defend politicians against citizens. 
This discourse about citizens' incompetence leads these MPs to develop a vision in which elected representation is the only legitimate form of participation and representation. These MPs see participation outside of elections as a series of informal and everyday interactions between voters and MPs, taking place in public events or in other settings. For instance, MP 15 (PS, Parliament of Brussels) argues:

"citizen participation is about discussing with people on Saturday morning at the market (...), about taking the pulse of his population on a daily basis"

MPs are seen as the "legal representatives" of voters who "choose for the collective interest" (MP12, PS, Parliament of Brussels). To use the famous distinction made by Burke (1776), these MPs see themselves as trustees who should have the full autonomy to deliberate and act for the greater good, without strict constraints from voters of their constituencies. Hence, they consider that if citizens want to play an active political role they should vote or run as a candidate in an election. For instance, MP 48 (MR, Federal Parliament) argues:

“citizens can vote, they can run for elections... If they don't want to do politics, if they don't want to run for election, if they vote badly... They shouldn't put all the blame on politicians".

Because of their purely elective vision of democracy, these MPs express outright rejection of any instrument of participation outside of elections. According to MP 52 (PS, Federal Parliament):

"Participatory democracy is a word that tarnishes democracy. (...) we give the impression that democracy is a dictatorship, that without participation it isn't democratic. No! Representatives are democratically elected! They are legitimate!" 
This discourse is elitist because it exacerbates the above arguments that more openly insist on citizens' political incompetence. Elections are considered as the only truly legitimate form of citizen participation and as the one and only source of legitimacy in democracy.

\section{Discussion and conclusion}

French-speaking Belgium is a crucial case that contributes to our understanding of MPs' positions on deliberative mini-publics, because public authorities have already implemented these instruments extensively. The large sample of MPs interviewed allows us to draw some conclusions about the profile of the supporters of DMPs and, more importantly, to provide a typology of MPs' discourses on deliberative mini-publics. Our article shows that most politicians analyse DMPs in redistributive terms and as instruments that could endanger their elective legitimacy (Table 2). This article develops on existing exploratory works conducted in Belgium (Jacquet et al. 2015, Schiffino et al. 2019). Thanks to our rich corpus, we identify two argumentative frames structuring MPs' discourses about DMPs: competence and vision of political representation.

\section{[Table 2 about Here]}

The true division in the discourses about DMPs lies between MPs who are willing to share part of their decision power with citizens and those who are not. Despite the lively debate questioning the importance of linking deliberation and decision (Lafont 2019), the evaluation of MPs does not rely on considerations on the virtues of deliberation, but mainly on their contrasting views on lay citizens' competence. This evaluation of citizens' capacity influences their conception of political representation. Indeed, arguments about capacity and representation are intertwined: the more MPs perceive citizens as incompetent, the more primacy they give to the election in the representative process. Those who see themselves as 
the only competent political actors able to consider the general interest also consider that all democratic legitimacy emanates from elections. They are particularly critical about DMPs and reject the very idea of sortition. By contrast, MPs who consider that all citizens are able to take part in discussions and decisions about complex policy issues also envision representation as a dynamic process of interaction in which elections are only one of the instruments of decision and participation. MPs who are willing to support binding DMPs come from left-wing opposition parties and have fewer political resources. In other words, they seem to compensate their relative lack of electoral legitimacy by promoting alternative forms of citizen participation. In light of these results, the likelihood of having DMPs with binding powers implemented in the near future in most consolidated democracies appear unlikely whereas there should not be much opposition to consultative DMPs.

This study shows that the discourses and the positions of MPs are far from being universally convinced of the many virtues of deliberation, even in a region where deliberative mini-publics have become a part of the political landscape. There is a huge gap between the academic vision of DMPs, that strongly focuses on the quality of deliberation and on the characteristics of the process, and on the views of political actors who mostly see these devices as power-sharing instruments and remain wary of the preservation of their existing prerogatives. Future research should investigate how political actors in countries and regions in which DMPs have not been as institutionalized envision deliberative mini-publics. Secondly, our study has focused on parliaments, which are the main centres of power in Belgium. One might expect that at the municipal level, where the value of proximity is more central and which deals with issues that are closer to citizens' everyday concerns, elected officials may be more welcoming of DMPs and may develop different discourses on the matter. Nevertheless, it is not really the case in Belgium as most of the DMPs are organised at the Federal and the Regional level (Vrydagh et al. 2020). This may be because the generally stronger legitimacy of elected officials at the 
local level (Muñoz 2017) may make these tools more superfluous to them. Finally, this article has not considered how the participation of politicians in DMPs could affect and change their perceptions and discourses about these instruments, and democratic innovations more generally. Future works on the perceptions of DMPs should not only compare countries, but also regions, levels of power, and familiarity with these instruments.

\section{References}

Bedock, C. (2017) Reforming Democracy: Institutional Engineering in Western Europe. Oxford: Oxford University Press.

Bedock, C., and Pilet, J.-B. (2020) Who Supports Citizens Selected by Lot to be the Main Policymakers? A Study of French Citizens. Government and Opposition, 1-20.

Best, V. (2020) Democracy Reform as a Populist Policy Supply. In S. Bukow and U. Jun (eds.), Continuity and Change of Party Democracies in Europe. Wiesbaden: Springer Fachmedien, pp. 203-251.

Biard, B., Bottin, J., Cogels, M., and Sabbe, M. (2020) Ecologists and Democracy in Belgium : an Analysis of Party Manifestos. Working Papers Constitution-making and deliberative democracy, (6). https://dial.uclouvain.be/pr/boreal/object/boreal\%3A229871/datastream/PDF_01/view

Boelaert, J., Michon, S., and Ollion, E. (2017) Métier : député - Enquête sur la professionnalisation de la politique en France. Paris: Raisons d'agir.

Bowler, S., Donovan, T., and Karp, J. A. (2002) When Might Institutions Change? Elite Support for Direct Democracy in Three Nations. Political Research Quarterly, 55(4): 731-754.

Bowler, S., Donovan, T., and Karp, J. A. (2006) Why Politicians Like Electoral Institutions: Self Interest, Values, or Ideology? Journal of Politics, 68(2): 434-446.

Braun, V., and Clarke, V. (2006) Using thematic analysis in psychology. Qualitative Research in Psychology, 3(2): 77-101.

Burke, E. (1997) Edmund Burke's Speech to the Electors of Bristol at the Conclusion of the Poll, November 1774: For Presentation to Members of the House of Commons at the Conclusion of the Poll, May 1997. Dublin: Merrion Press for the Edmund Burke Society. 
Chambers, S. (2003) Deliberative Democratic Theory. Annual Review of Political Science, 6(1): 307-326.

Christensen, H. S., and von Schoultz, Å. (2019) Ideology and Deliberation: An Analysis of Public Support for Deliberative Practices in Finland. International Journal of Public Opinion Research, 31(1): 178-194.

Clarke, N., Jennings, W., Moss, J., and Stoker, G. (2018). The Good Politician: Folk Theories, Political Interaction, and the Rise of Anti-Politics. Cambridge: Cambridge University Press.

Converse, P. E. (1964). The Nature of Belief Systems in Mass Publics. In D. E. Apter (ed.), Ideology and discontent. New York: The Free Press of Glencoe, pp. 206-261.

Farrell, D. M., Suiter, J., Cunningham, K., and Harris, C. (2020) When Mini-Publics and Maxi-Publics Coincide: Ireland's National Debate on Abortion. Representation, 0(0), 1-19. https://doi.org/10.1080/00344893.2020.1804441

Fournier, P., Kolk, H. V. D., Carty, R. K., Blais, A., and Rose, J. (2011) When Citizens Decide: Lessons from Citizens' Assemblies on Electoral Reform. Oxford: Oxford University Press.

Fung, A., and Abers, R. (2003) Deepening Democracy: Institutional Innovations in Empowered Participatory Governance. London: Verso.

Gerring, J. (2006) Case Study Research: Principles and Practices. Cambridge: Cambridge University Press.

Gherghina, S., and Geissel, B. (2020) Support for direct and deliberative models of democracy in the UK: understanding the difference. Political Research Exchange, 2(1), 1809474. https://doi.org/10.1080/2474736X.2020.1809474

Gherghina, S., Soare, S., and Jacquet, V. (2020) Deliberative democracy and political parties: functions and consequences. European Political Science, 19(2): 200-211.

Goodin, R. E. (2008) Innovating Democracy: Democratic Theory and Practice After the Deliberative Turn. Oxford: Oxford University Press.

Gourgues, G. (2013) Les politiques de démocratie participative. Grenoble: Presses Universitaires de Grenoble.

Grönlund, K., Bächtinger, A., and Setälä, M. (eds.). (2014) Deliberative Mini-Publics: Involving Citizens in the Democratic Process. Colchester: ECPR Press.

Guasti, P., and Geissel, B. (2019) Saward's Concept of the Representative Claim Revisited: An Empirical Perspective. Politics and Governance, 7(3): 98-111. 
Heinelt, H. (2013) Councillors' Notions of Democracy, and their Role Perception and Behaviour in the Changing Context of Local Democracy. Local Government Studies, 39(5): 640-660.

Jacquet, V. (2017) Explaining non-participation in deliberative mini-publics. European Journal of Political Research, 56(3): 640-659.

Jacquet, V., Niessen, C., and Reuchamps, M. (2020) Sortition, its advocates and its critics: An empirical analysis of citizens' and MPs' support for random selection as a democratic reform proposal. International Political Science Review, 0192512120949958. https://doi.org/10.1177/0192512120949958

Jacquet, V., Schiffino, N., Reuchamps, M., and Latinis, D. (2015) Union sacrée ou union forcée ? Les parlementaires belges face à l’impératif délibératif. Participations, 13(3): 171-203.

Junius, N., Matthieu, J., Caluwaerts, D., and Erzeel, S. (2020) Is it interests, ideas or institutions? Explaining elected representatives' positions towards democratic innovations in 15 European countries. Frontiers in Political Science, 2. https://doi.org/10.3389/fpos.2020.584439

Lafont, C. (2019) Democracy without Shortcuts: A Participatory Conception of Deliberative Democracy. Oxford: Oxford University Press.

Lawrence, E. D., Donovan, T., and Bowler, S. (2009) Adopting Direct Democracy: Tests of Competing Explanations of Institutional Change. American Politics Research, 37(6): $1024-1047$.

Lovenduski, J., and Norris, P. (1993) Gender and Party Politics. Thousand Oaks, Calif.

Manin, B. (1997). The principles of representative government. Cambridge: Cambridge University Press.

Mucchielli, A., and Paillé, P. (2012) L'analyse qualitative en sciences humaines et sociales. Paris: Armand Colin.

Mudde, C. (2007) Populist Radical Right Parties in Europe. Cambridge: Cambridge University Press.

Muñoz, J. (2017). Political trust and multilevel government. In S. Zmerli \& T. W. g. Van Der Meer (Eds.), Handbook on Political Trust (pp. 69-88). Cheltenham: Edward Elgar Publishing.

Newton, K., and Geissel, B. (eds.). (2012) Evaluating Democratic Innovations: Curing the Democratic Malaise? London: Routledge. 
Niessen, C. (2019) When citizen deliberation enters real politics: how politicians and stakeholders envision the place of a deliberative mini-public in political decisionmaking. Policy Sciences, 52(3): 481-503.

Niessen, C., and Reuchamps, M. (2020) Institutionalising Citizen Deliberation in Parliament: The Permanent Citizens' Dialogue in the German-speaking Community of Belgium. Parliamentary Affairs. https://doi.org/10.1093/pa/gsaa056

Niessen, C., Schiffino, N., Jacquet, V., and Descamps, L. (2019) Critical Candidates: Elite Attitudes Towards the Functioning of Representative Democracy. In A. Vandeleene, L. De Winter, and P. Baudewyns (eds.), Candidates, Parties and Voters in the Belgian Partitocracy, Cham: Springer International Publishing, pp. 341-363.

Núñez, L., Close, C., and Bedock, C. (2016) Changing Democracy? Why Inertia Is Winning Over Innovation. Representation, 52(4); 341-357.

Paoletti, M. (1997) La démocratie locale et le référendum: Analyse de la démocratie locale à travers la genèse institutionnelle du référendum. Paris: L'Harmattan.

Paoletti, M., and Rui, S. (2015) Introduction. La démocratie participative a-t-elle un sexe? Participations, (12): 5-29.

Parkinson, J., and Mansbridge, J. (2012) Deliberative Systems: Deliberative Democracy at the Large Scale. Cambridge: Cambridge University Press.

Pateman, C. (2012) Participatory Democracy Revisited. Perspectives on Politics, 10(1): 7-19. Patton, M. Q. (2015). Qualitative Research \& Evaluation Methods : Integrating Theory and Practice (4th edition.). Thousand Oaks, California: SAGE Publications.

Paulis, E., Pilet, J.-B., Panel, S., Vittori, D., and Close, C. (2020) The POLITICIZE dataset: an inventory of deliberative mini-publics (DMPs) in Europe. European Political Science. https://doi.org/10.1057/s41304-020-00284-9

Petit, G. (2017) Pouvoir et vouloir participer en démocratie : sociologie de l'engagement participatif : la production et la réception des offres institutionnelles de participation à l'échelle municipale. Université Panthéon-Sorbonne - Paris I, Paris.

Pilet, J., Verlet, D., Heyerick, A., Delwit, P., and Block, T. (2007) Participatory democracy in Belgium. Between the politician's mistrust and citizen apathy. In Towards DIYPolitics? Participatory and Direct Democracy at the Local Level in Europe. Vanden Broele, pp. 191-212. 
Reuchamps, M., Caluwaerts, D., Dodeigne, J., Jacquet, V., Moskovic, J., and Devillers, S. (2017) Le G1000 : une expérience citoyenne de démocratie délibérative. Courrier hebdomadaire du CRISP, 2344-2345(19-20): 5-104.

Reuchamps, M., and Suiter, J. (eds.). (2016) Constitutional Deliberative Democracy in Europe. Colchester: ECPR Press.

Ritchie, J., Lewis, J., Elam, G., Tennant, R., and Rahim, N. (2014) Designing and selecting samples. In J. Ritchie, J. Lewis, C. Mc Naughton Nichols, and R. Ormstorn (Eds.), Qualitative research practice (2nd ed.), London: SAGE Publications, pp. 111-142.

Rojon, S., Rijken, A. J., and Klandermans, B. (2019) A Survey Experiment on Citizens' Preferences for 'Vote-Centric' vs. 'Talk-Centric' Democratic Innovations with Advisory vs. Binding Outcomes. Politics and Governance, 7(2): 213-226.

Saward, M. (2010) The Representative Claim. Oxford: Oxford University Press.

Scarrow, S. E. (1999). Parties and the expansion of direct democracy. Party Politics, 5(3): $341-362$.

Schiffino, N., Jacquet, V., Cogels, M., and Reuchamps, M. (2019) Les gouvernants face aux transformations de la démocratie. Gouvernement et action publique, 8(2): 57-80.

Schmidt, V. A. (2013). Democracy and Legitimacy in the European Union Revisited: Input, Output and 'Throughput'. Political Studies, 61(1): 2-22.

Sinardet, D. (2012) Is There a Belgian Public Sphere? What the Case of a Federal Multilingual Country Can Contribute to the Debate on Transnational Public Spheres, and Vice Versa. In M. Seymour and A.-G. Gagnon (eds.), Multinational Federalism: Problems and Prospects Basingstoke: Palgrave Macmillan, pp. 172-202.

Sintomer, Y., and Blondiaux, L. (2002) L’impératif délibératif. Politix, 15(57): 17-35.

Sintomer, Y., Röcke, A., and Herzberg, C. (2016) Participatory Budgeting in Europe: Democracy and public governance. London: Routledge.

Sintomer, Y., and Talpin, J. (eds.). (2011) La démocratie participative au-delà de la proximité: Le Poitou-Charentes et l'échelle régionale. Rennes: Presses universitaires de Rennes.

Smith, G. (2009) Democratic Innovations: Designing Institutions for Citizen Participation. Cambridge: Cambridge University Press.

Tsebelis, G. (1990) Nested games: rational choice in comparative perspective. Berkeley: University of California Press.

Urbinati, N., and Warren, M. E. (2008) The Concept of Representation in Contemporary Democratic Theory. Annual Review of Political Science, 11(1): 387-412. 
van Haute, E., Amjahad, A., Borriello, A., Close, C., and Sandri, G. (2013) Party members in a pillarised partitocracy. An empirical overview of party membership figures and profiles in Belgium. Acta Politica, 48(1): 68-91.

Vandamme, P.-É. (2018) Le tirage au sort est-il compatible avec l'élection ? Revue française de science politique, 68(5): 873-894.

Vandamme, P.-É., Jacquet, V., Niessen, C., Pitseys, J., and Reuchamps, M. (2018) Intercameral Relations in a Bicameral Elected and Sortition Legislature. Politics and Society, 46(3): 381-400.

Vetter, A., Heinelt, H., and Rose, L. E. (2018) Mayor's notions of local democracy. In H. Heinelt, A. Magnier, M. Cabria, and H. Reynaert (eds.), Political Leaders and Changing Local Democracy : The European Mayor Basingstoke: Palgrave MacMillan, pp. 173-208.

Vrydagh, J., Devillers, S., Talukder, D., Jacquet, V., \& Bottin, J. (2020). Les mini-publics en Belgique (2001-2018) : expériences de panels citoyens délibératifs. Courrier hebdomadaire du CRISP, $\mathrm{n}^{\circ}$ 2477-2478(32), 5-72.

Warren, M. E., and Pearse, H. (2008) Designing Deliberative Democracy: The British Columbia Citizens’ Assembly. Cambridge: Cambridge University Press. 
Table 1. Position of the MPs interviewed on binding mini-publics, consultative mini-publics and popular consultations

\begin{tabular}{ccccc} 
& $\begin{array}{c}\text { In favour of } \\
\text { binding mini- } \\
\text { publics }\end{array}$ & $\begin{array}{c}\text { In favour of } \\
\text { consultative } \\
\text { mini-publics }\end{array}$ & $\begin{array}{c}\text { Against both } \\
\text { forms of mini- } \\
\text { publics }\end{array}$ & $\begin{array}{c}\text { Total MPs } \\
\text { (sample) }\end{array}$ \\
\hline Women & $32 \%$ & $\mathbf{9 7 \%}$ & $\mathbf{0 \%}$ & 33 \\
Men & $19 \%$ & $\mathbf{7 5 \%}$ & $\mathbf{2 0 \%}$ & 58
\end{tabular}

Party

$\begin{array}{ccccc}\text { CDH } & \mathbf{4 4 \%} & 80 \% & 0 \% & 11 \\ \text { DéFi } & \mathbf{0 \%} & 80 \% & 20 \% & 10 \\ \text { MR } & \mathbf{5 \%} & 76 \% & 20 \% & 23 \\ \text { PS } & \mathbf{2 2 \%} & 81 \% & 16 \% & 33 \\ \text { Ecolo } & \mathbf{6 3 \%} & 100 \% & 0 \% & 12 \\ \text { Others* } & \mathbf{5 0 \%} & 100 \% & 0 \% & 2\end{array}$

Age

$\begin{array}{lcccc}20-39 & 29 \% & 79 \% & 14 \% & 14 \\ 40-49 & 36 \% & 83 \% & 14 \% & 29 \\ 50-59 & 5 \% & 91 \% & 9 \% & 25 \\ 60 \text { and more } & 24 \% & 77 \% & 14 \% & 23\end{array}$

Status

$\begin{array}{ccccc}\text { Majority } & \mathbf{1 4 \%} & 82 \% & 14 \% & 49 \\ \text { Opposition } & \mathbf{3 4 \%} & 83 \% & 12 \% & 42\end{array}$

Parliament

$\begin{array}{ccccc}\text { Brussels } & \mathbf{2 9 \%} & 85 \% & 9 \% & 42 \\ \text { Federal } & \mathbf{5 \%} & 81 \% & 19 \% & 22 \\ \text { Wallonia } & \mathbf{2 9 \%} & 79 \% & 13 \% & 27\end{array}$

Multiple office holders

$\begin{array}{lllll}\text { No } & \mathbf{3 1 \%} & 85 \% & 9 \% & 53 \\ \text { Yes } & \mathbf{1 2 \%} & 79 \% & 18 \% & 38\end{array}$

Number of mandates

\begin{tabular}{ccccc} 
Two or less & $\mathbf{3 4 \%}$ & $84 \%$ & $12 \%$ & 52 \\
Three or more & $\mathbf{9 \%}$ & $81 \%$ & $14 \%$ & 39 \\
\hline TOTAL & $23 \%$ & $83 \%$ & $13 \%$ & 91 \\
\hline $\mathrm{N}$ & 85 & 87 & 86
\end{tabular}

*This category includes one independent MP and one MP from the party PTB

Note: Items in bold are differences that are statistically significant at the 10\% level according to the chi-square test. These results should be interpreted with caution due to the small numbers per category. 
Table 2. Typology of discourses of MPs about deliberative mini-publics

\begin{tabular}{|c|c|c|c|}
\hline & $\begin{array}{l}\text { Power-sharing } \\
\text { discourse }\end{array}$ & $\begin{array}{l}\text { Consultation } \\
\text { discourse }\end{array}$ & Elitist discourse \\
\hline Preferred forms of DMPs & $\begin{array}{l}\text { DMPs on major issues } \\
\text { with binding decision } \\
\text { powers composed by } \\
\text { sortition }\end{array}$ & $\begin{array}{c}\text { Consultative DMPs } \\
\text { on local issues with } \\
\text { no binding decision } \\
\text { power composed by } \\
\text { self-selection }\end{array}$ & $\begin{array}{l}\text { Rejection of all } \\
\text { forms of DMPs }\end{array}$ \\
\hline Evaluation of citizens' competence & $\begin{array}{l}\text { Politicians and citizens } \\
\text { placed on an equal } \\
\text { ground and universally } \\
\text { competent }\end{array}$ & $\begin{array}{l}\text { Many incompetent } \\
\text { and unmotivated } \\
\text { citizens who should } \\
\text { not take part in DMPs }\end{array}$ & $\begin{array}{c}\text { Citizens seen as } \\
\text { incompetent, selfish } \\
\text { and unable to } \\
\text { consider the general } \\
\text { interest }\end{array}$ \\
\hline $\begin{array}{c}\text { Definition of } \\
\text { political representation }\end{array}$ & $\begin{array}{l}\text { Permanent processes of } \\
\text { co-construction and co- } \\
\text { decision with citizens } \\
\text { alongside elections }\end{array}$ & $\begin{array}{l}\text { Election as the main } \\
\text { process of } \\
\text { representation } \\
\text { complemented by } \\
\text { regular consultations } \\
\text { of the citizens }\end{array}$ & $\begin{array}{l}\text { Election as the only } \\
\text { source of legitimacy } \\
\text { and citizen } \\
\text { participation }\end{array}$ \\
\hline Typical profile & $\begin{array}{c}\text { Green and left-wing MPs } \\
\text { with limited political } \\
\text { experience and access to } \\
\text { political power }\end{array}$ & No typical profile & $\begin{array}{l}\text { Male from traditional } \\
\text { governing parties }\end{array}$ \\
\hline
\end{tabular}


Word count: 8557 words

Date of the manuscript: June 2021 